\title{
Solar Hydrogen from Glycerol-Water Mixture
}

\author{
Chong Fai Kait, Ela Nurlaela \\ Universiti Teknologi PETRONAS \\ Bandar Seri Iskandar, 31750 Tronoh \\ Perak, Malaysia.
}

\author{
Binay K. Dutta \\ West Bengal Pollution Control Board \\ Paribesh Bhawan, Salt Lake \\ Kolkata 700 098, India.
}

Received: February 22, 2021 Revised: March 10, 2021. Accepted: March 14, 2021. Published: March 26, 2021.

\begin{abstract}
The photocatalytic activity of titania supported bimetallic $\mathrm{Cu}-\mathrm{Ni}$ photocatalysts were assessed for hydrogen production from water and also a mixture of glycerol-water system under visible light illumination. Addition of $2.0 \mathrm{~mL}$ glycerol to $8.0 \mathrm{~mL}$ water enhanced the solar hydrogen production from $6.1 \mathrm{~mL}$ to $9.5 \mathrm{~mL}$. If metal was not incorporated onto $\mathrm{TiO}_{2}$, the hydrogen production was minimal, $2.0 \mathrm{~mL}$ after $2 \mathrm{hr}$ reaction. The band gap for bimetallic $\mathrm{Cu}-\mathrm{Ni} / \mathrm{TiO}_{2}$ was $2.78 \mathrm{eV}$ compared to $3.16 \mathrm{eV}$ for $\mathrm{TiO}_{2}$. Photooxidation of glycerol produced glyceraldehyde, glycolic acid and oxalic acid.
\end{abstract}

Keywords- Cu-Ni bimetallic; solar hydrogen; visible light; glycerol

\section{INTRODUCTION}

Hydrogen can be produced from various processes and the trend is moving from fossil fuels feedstock into renewable resources [1]. Solar hydrogen production from water offers an attractive and sustainable option since water is in abundance and the energy source from the sun is free. Titania, $\mathrm{TiO}_{2}$ is the most popular photocatalyst used for solar hydrogen production [2]. However, due to its high band gap, the efficiency in visible light is low. The low efficiency of photohydrogen production is mainly due to the inability of $\mathrm{TiO}_{2}$ to utilize visible light. The bandgap of $\mathrm{TiO}_{2}$ is about $3.2 \mathrm{eV}$ meaning that it can only be activated by photons with wavelength $\geq 400 \mathrm{~nm}$ (UV region). Since solar radiation consists of $3-4 \%$ UV component, visible light-active photocatalyst is a crucial requirement for economically feasible hydrogen production.

The low efficiency of photohydrogen production was also due to recombination reaction of photogenerated electrons and holes. Research on reducing the band gap has been vigorously conducted on water system by the incorporation of nonmetal [3] and metal components [4-5] and also with the addition of hole scavengers [6-7]. Some metals such as $\mathrm{Cu}, \mathrm{Ag}, \mathrm{Au} \mathrm{Ni}$, $\mathrm{Rh}, \mathrm{Pt}$ and $\mathrm{Zn}$ were capable to increase the catalytic activity of the photocatalyst enhancing the hydrogen production [8-9]. Supported bimetallic catalysts have been widely used in industrial fields [10]. Bimetallic $\mathrm{Cu}-\mathrm{Ni}$ has been reported to enhance carbon dioxide hydrogenation [11] and photocatalytic reduction of nitrates [12]. Hole scavengers are chemical species added into a photocatalytic system in order to stabilize the photogenerated holes, to prevent the electron-hole recombination process. The hole scavengers undergo oxidation process. It would be beneficial if value-added products could be formed from the photoreaction.

Glycerol is a by-product from transesterification of fats and oils to produce biodiesel and also from the hydrolysis of palm oil (or other oils and fats) in soap and fatty acids manufacturing. This has caused an oversupply of glycerol. The photo-oxidation of glycerol was conducted using titania, $\mathrm{TiO}_{2}$ [13-14] under the irradiation of UV light to produce useful chemicals such as dihydroxyacetone, glycolaldehyde, glyceraldehyde, formic acid and $\mathrm{CO}_{2}$. Besides the production of glycerol derivatives, hydrogen has also been produced using $\mathrm{TiO}_{2}$ doped with Pt [15], Au and Pd [16], Cu [17-19] and $\mathrm{Ni}$ [19]. However, the reactions were conducted under the irradiation of UV light.

In this study, bimetallic $10 \mathrm{wt} \% \mathrm{Cu}-\mathrm{Ni} / \mathrm{TiO}_{2}$ and monometallic $\quad 10 \mathrm{wt} \% \mathrm{Cu} / \mathrm{TiO}_{2}$ and $10 \mathrm{wt} \% \mathrm{Ni} / \mathrm{TiO}_{2}$ photocatalysts were prepared, characterized and investigated for solar hydrogen production under visible light. It is expected that the activity region of the photocatalyst will be shifted to the visible light by metal doping. The addition of glycerol, which acts as hole scavenger will be able to enhance the hydrogen production efficiency. Products from the photooxidation process were also analyzed.

\section{METHODOLOGY}

\section{A. Preparation of $\mathrm{Cu}-\mathrm{Ni} / \mathrm{TiO}_{2}$ Photocatalyst}

Degussa P25 $\mathrm{TiO}_{2}$ was used as the support for all the photocatalysts. Bimetallic photocatalysts with $10 \mathrm{wt} \%$ total metal loading were prepared via co-precipitation method to investigate the effect of $\mathrm{Cu}: \mathrm{Ni}$ mass composition on solar hydrogen production efficiency. The monometallics $10 \mathrm{wt} \%$ $\mathrm{Cu} / \mathrm{TiO}_{2}$ and $10 \mathrm{wt} \% \mathrm{Ni} / \mathrm{TiO}_{2}$ were also prepared in addition to $\mathrm{TiO}_{2}$ as references. The metal precursors were copper(II) nitrate trihydrate (Acros, $>98 \%$ purity) and nickel(II) nitrate hexahydrate (Acros, $>98 \%$ purity). Glycerol (Systerm, 95\% purity) was used as a templating agent while sodium hydroxide, $\mathrm{NaOH}$ (Merck, 95\%), was used as the precipitating agent. All the materials were used as received without further purification. Known amounts of $\mathrm{Cu}\left(\mathrm{NO}_{3}\right)_{2} \cdot 3 \mathrm{H}_{2} \mathrm{O}$ and/or $\mathrm{Ni}\left(\mathrm{NO}_{3}\right)_{2} \cdot 6 \mathrm{H}_{2} \mathrm{O}$ were weighed and dissolved in distilled water followed by the addition of glycerol. The solution was stirred continuously prior to addition of $\mathrm{TiO}_{2}$. The slurry was stirred 
for another hour before adding $0.25 \mathrm{M} \mathrm{NaOH}$ dropwise until $\mathrm{pH}=12$ to form precipitates. The mixture was aged for 1 day, filtered and dried overnight at $75^{\circ} \mathrm{C}$ in an oven. Calcination was conducted at $200^{\circ} \mathrm{C}$ for $1 \mathrm{hr}$. The effect of total metal loading on the performance for solar hydrogen production was also investigated. The drying and calcination temperatures and durations were selected based on previous study reported elsewhere [20].

\section{B. Characterization of $\mathrm{Cu}-\mathrm{Ni} / \mathrm{TiO}_{2}$ Photocatalyst}

The bimetallic, monometallic and $\mathrm{TiO}_{2}$ photocatalysts were characterized using powder X-ray diffraction (XRD), field emission scanning electron microscopy (FESEM) and diffuse reflectance UV-Vis spectroscopy (DRUV-Vis).

The photocatalysts were analysed for the type of $\mathrm{TiO}_{2}$ phases present using Bruker D8 Advance with $\mathrm{CuK}_{\alpha}$ radiation $(40 \mathrm{kV}, 40 \mathrm{~mA})$ at $2 \theta$ angles from $10^{\circ}$ to $80^{\circ}$, with a scan speed of $4^{\circ} \mathrm{min}^{-1}$. The morphology of the photocatalysts such as crystallite shape, size, and size distribution were analyzed using FESEM. The analyses were conducted using Zeiss Supra $35 \mathrm{VP}$ with $80 \mathrm{kX}$ magnification and operating at $10 \mathrm{kV}$. DRUV-Vis measurement was performed using a Shimadzu Spectrometer 3150, equipped with an integrating sphere. $\mathrm{BaSO}_{4}$ was employed as the reference material with analysis ranging from 190 to $800 \mathrm{~nm}$. This technique is used to determine any shifting of the absorption edge to the visible region for the photocatalysts due to metal incorporation. The band gap energies of the photocatalysts could be determined from the Kubelka-Munk function, $F(R)$, using the Tauc plot, a plot of $(\mathrm{F}(\mathrm{R}) \cdot \mathrm{h} v)^{1 / 2}$ against $\mathrm{h} v$.

\section{Solar Hydrogen Production}

The photocatalysts were evaluated for solar hydrogen production using a multiport photocatalytic reactor integrated to water displacement units (Fig. 1) to monitor any gaseous product. A $500 \mathrm{~W}$ halogen lamp was used to simulate visible light, irradiating the photoreactor from the top giving an intensity of 12.2 klux.

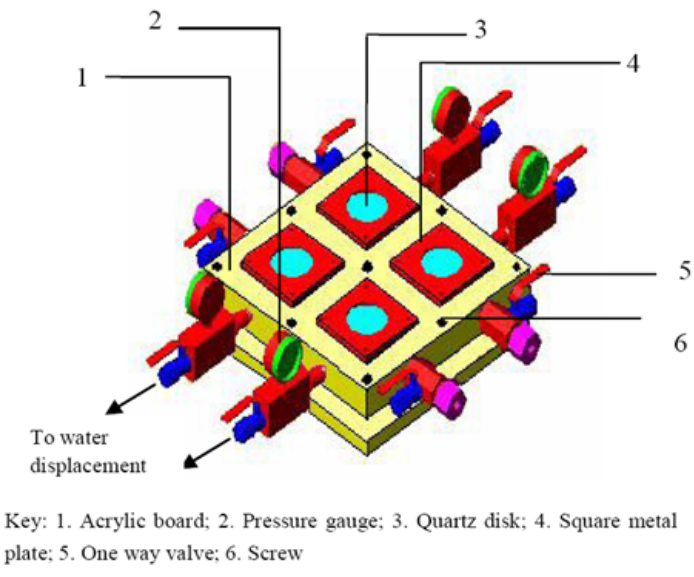

Fig. 1. Schematic of the multiport photocatalytic reactor

A $0.1 \mathrm{~g}$ of photocatalyst powder was suspended in distilled water $(8.0 \mathrm{~mL})$ and placed in the multiport reactor. The amount of gas evolved was monitored for $2 \mathrm{hr}$. The gaseous product was analyzed using a gas chromatograph (Agilent 6890 series GC system) with 5A molecular sieve column (capillary $45.0 \mathrm{~m}$ $\times 530 \mu \mathrm{m} \times 25 \mu \mathrm{m})$ and equipped with thermal conductivity detector. Helium gas was used as the carrier gas.

For experiments where liquid glycerol was added as hole scavenger, the volume of glycerol was varied from $2.0 \mathrm{~mL}$ to $8.0 \mathrm{~mL}$. Products from the photooxidation process were analyzed using high performance liquid chromatography (HPLC) (Agilent 1100 series) equipped with a Transgenomic column (ICE-ORH-801) and $0.01 \mathrm{~N} \mathrm{H}_{2} \mathrm{SO}_{4}$ as eluent.

\section{RESULTS AND DISCUSSION}

\section{A. Preparation of $\mathrm{Cu}-\mathrm{Ni} / \mathrm{TiO}_{2}$ Photocatalyst}

Bimetallic photocatalysts were prepared to investigate the effects of $\mathrm{Cu}: \mathrm{Ni}$ mass composition, and total metal loading on the performance for solar hydrogen production. The $10 \mathrm{wt} \%$ monometallic photocatalysts were also prepared. Calcination was conducted at $200^{\circ} \mathrm{C}$ for $1 \mathrm{~h}$ duration. These pretreatment conditions were the optimum conditions selected based on previous work [20]. The photocatalysts were given denotation of $10 \mathrm{wt} \%$ 9Cu1Ni for the bimetallic photocatalyst with $9: 1$ $\mathrm{Cu}: \mathrm{Ni}$ mass composition while $10 \mathrm{wt} \%$ 10 $10 \mathrm{Cu}$ and $10 \mathrm{wt} \%$ 10Ni were used for the monometallic $\mathrm{Cu}$ and $\mathrm{Ni}$ photocatalysts, respectively.

\section{B. Characterization of $\mathrm{Cu}-\mathrm{Ni} / \mathrm{TiO}_{2}$ Photocatalyst}

Characterization procedures were conducted to determine the bulk and surface properties of the photocatalysts.

\section{1) $X R D$}

Fig. 2 shows the XRD patterns of the photocatalysts and $\mathrm{TiO}_{2}$. The peaks were mainly characteristic peaks of the anatase phase at $2 \theta=25.3^{\circ}, 33.8^{\circ}, 47.8^{\circ}, 53.8^{\circ}$ and $55.0^{\circ}$, while the rutile phase was represented by peaks at $2 \theta=27.4^{\circ}$ and $41.5^{\circ}$. It was found that no characteristic peaks representing $\mathrm{Cu}$ - or $\mathrm{Ni}$-species could be detected indicating that the metal particles were well dispersed on $\mathrm{TiO}_{2}$. The presence of glycerol during photocatalyst preparation contributed to the high metal dispersion [21-22]. The average crystallite size calculated using Scherrer equation was $35 \mathrm{~nm}$.

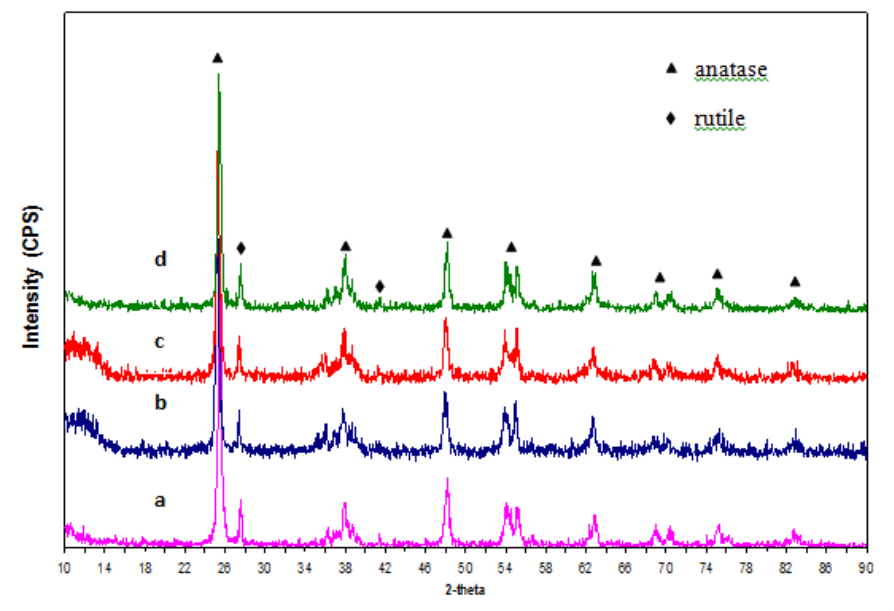

Fig. 2. XRD patterns of (a) $\mathrm{TiO}_{2}$, (b) $10 \mathrm{wt} \%$ _ $9 \mathrm{Cu} 1 \mathrm{Ni}$, (c) $10 \mathrm{wt} \% 10 \mathrm{Cu}$ and (d) $10 \mathrm{wt} \% 10 \mathrm{Ni}$ 


\section{2) FESEM}

The FESEM images represented in Fig. 3 shows that the photocatalysts were present as uniform spherical shaped particles. All the photocatalysts tend to display slight agglomeration. The particle size of the photocatalysts ranged from 20-40 nm, in good agreement with the crystallite size calculated from the XRD data. However, no indication of localized metal deposition was observed, which was also confirmed by the XRD results - as the result of high metal dispersion [22].
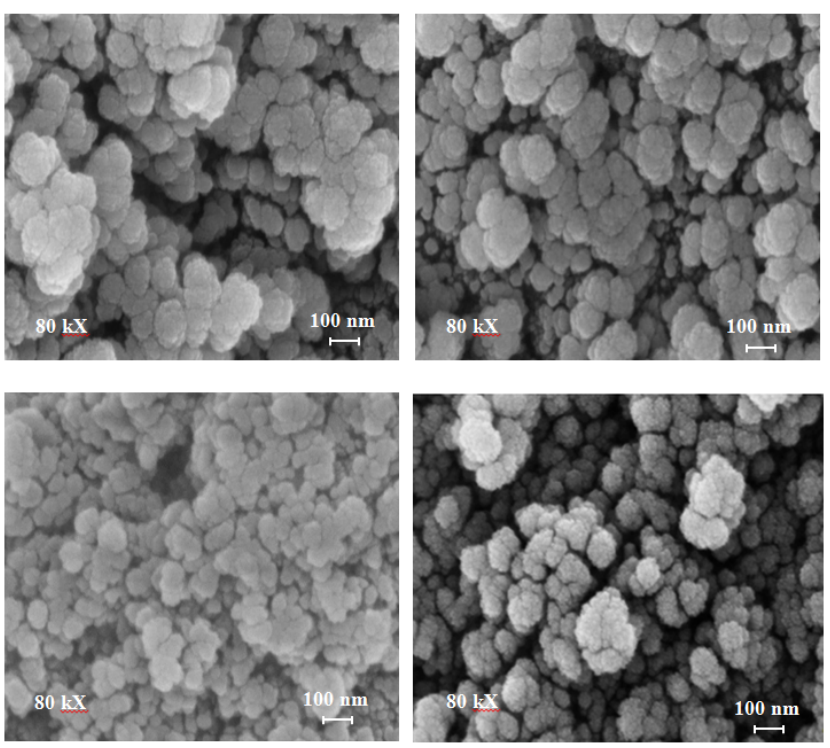

Fig. 3. FESEM images of (a) $10 \mathrm{wt} \% 9 \mathrm{Cu} 1 \mathrm{Ni}$,

(b) $10 \mathrm{wt} \% \_10 \mathrm{Cu}$, (c) $10 \mathrm{wt} \% \_10 \mathrm{Ni}$ and (d) $\mathrm{TiO}_{2}$

\section{3) $\mathrm{DR} U V-\mathrm{Vis}$}

DRUV-Vis spectrum of $\mathrm{TiO}_{2}$ in Fig. 4 showed its absorption edge at $400 \mathrm{~nm}$. No absorption was observed in the visible region. However, the edge shifted to the visible region with the addition of $\mathrm{Cu}, \mathrm{Ni}$ or $\mathrm{Cu}-\mathrm{Ni}$ indicating reduction in band gap values. Using Tauc plot (not shown), the band gaps were calculated and displayed in Table $\mathrm{I}$. $\mathrm{TiO}_{2}$ has the highest band gap of $3.16 \mathrm{eV}$. The addition of monometallic $\mathrm{Cu}$ or $\mathrm{Ni}$ reduced the band gap to $2.98 \mathrm{eV}$. Surface modification of $\mathrm{TiO}_{2}$ with $\mathrm{Cu}, \mathrm{Ni}$ or $\mathrm{Cu}-\mathrm{Ni}$ could significantly reduce the band gap thus shifting the absorption edge to the visible region [23-25]. The lowest band gap was displayed by $10 \mathrm{wt} \%$ _ $9 \mathrm{Cu} 1 \mathrm{Ni}$, $2.78 \mathrm{eV}$.

The presence of metal not only increased the visible light absorption, it also enhanced the absorbance in the UV region (wavelength $<400 \mathrm{~nm}$ ) as indicated by the higher absorbance of the bimetallic and monometallic photocatalysts compared to $\mathrm{TiO}_{2}$ in Fig. 4. $10 \mathrm{wt} \%$ 10Ni displayed the highest absorbance of approx. 0.19 followed by both $10 \mathrm{wt} \% 10 \mathrm{Cu}$ and $10 \mathrm{wt} \%$ 9 $\mathrm{Cu} 1 \mathrm{Ni}$, and finally by $\mathrm{TiO}_{2}$ displaying the lowest absorbance. The presence of $\mathrm{Ni}$ in $10 \mathrm{wt} \%$ - $\mathrm{Cu} 1 \mathrm{Ni}$ seemed to enhance its visible light harvesting property. $10 \mathrm{wt} \%$ - $9 \mathrm{Cu} 1 \mathrm{Ni}$ displayed the highest absorbance in the visible wavelength, and extending through to $800 \mathrm{~nm}$. This was followed by $10 \mathrm{wt} \% 10 \mathrm{Cu}$ and $10 \mathrm{wt} \% 10 \mathrm{Ni}$ and finally $\mathrm{TiO}_{2}$ displaying zero absorbance in the visible region.

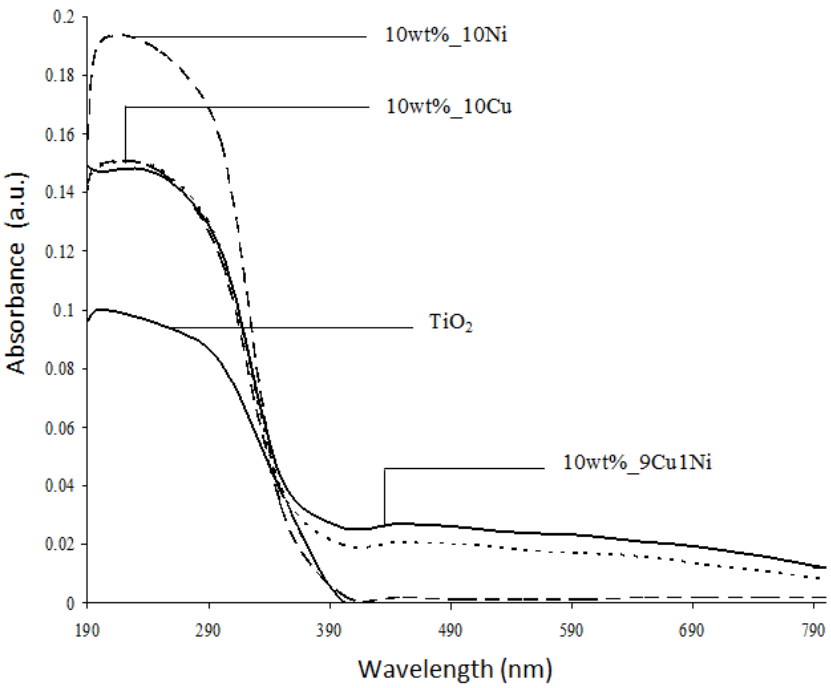

Fig. 4. DRUV-Vis spectra of the photocatalysts.

TABLE I. BAND GAP OF PHOTOCATALYSTS

\begin{tabular}{|l|c|}
\hline \multicolumn{1}{|c|}{ Photocatalyst } & Band gap, eV \\
\hline $\mathrm{TiO}_{2}$ & 3.16 \\
\hline $10 \mathrm{wt} \% \_10 \mathrm{Cu}$ & 2.98 \\
\hline $10 \mathrm{wt} \%$ 9Cu1Ni & 2.78 \\
\hline $10 \mathrm{wt} \%$ _Cu3Ni & 2.98 \\
\hline $10 \mathrm{wt} \% \_10 \mathrm{Ni}$ & 2.98 \\
\hline
\end{tabular}

\section{Solar Hydrogen Production}

Referring to Fig. 5, the effect of $\mathrm{Cu}$ :Ni mass composition on the solar hydrogen production efficiency was investigated. Bimetallic 10wt\%_9Cu1Ni photocatalyst displayed the highest hydrogen production of $6.1 \mathrm{~mL}$ compared to monometallic $10 \mathrm{wt} \% \_10 \mathrm{Cu}$ and $10 \mathrm{wt} \% 10 \mathrm{Ni}$, giving $5.0 \mathrm{~mL}$ and $4.3 \mathrm{~mL}$, respectively. $\mathrm{TiO}_{2}$ was able to produce only $2.0 \mathrm{~mL}$ gas. The reduction in band gap (Table I) for the photocatalysts compared to $\mathrm{TiO}_{2}$ has led to an increase in hydrogen production from water.

The addition of a small amount of $\mathrm{Ni}$ onto $\mathrm{Cu} / \mathrm{TiO}_{2}$ $(10 \mathrm{wt} \%$ - $\mathrm{Cu} 1 \mathrm{Ni})$ was able to enhance the performance of the photocatalyst from producing $5.0 \mathrm{~mL}$ to $6.1 \mathrm{~mL}$ hydrogen. This may be due to $\mathrm{Cu}$ acting as both hole and electron traps [26] while $\mathrm{Ni}$ as hole trap only [27]. However, as the composition of $\mathrm{Ni}$ increased $(10 \mathrm{wt} \%$ _ $7 \mathrm{Cu} 3 \mathrm{Ni})$, detrimental effect was observed resulting in lower amount of hydrogen produced. The increase in the amount of Ni led to it becoming the hole accumulation site which could attract the photogenerated electrons causing electron-hole recombination. During photoreaction, hydrogen should be produced together with oxygen. However, no oxygen was detected from the gas chromatography. This may be attributed to the oxygen itself acting as an electron acceptor leading to the formation of superoxide radical anions [28]. This may retard the continuous production of hydrogen causing the deactivation of the photocatalyst. 


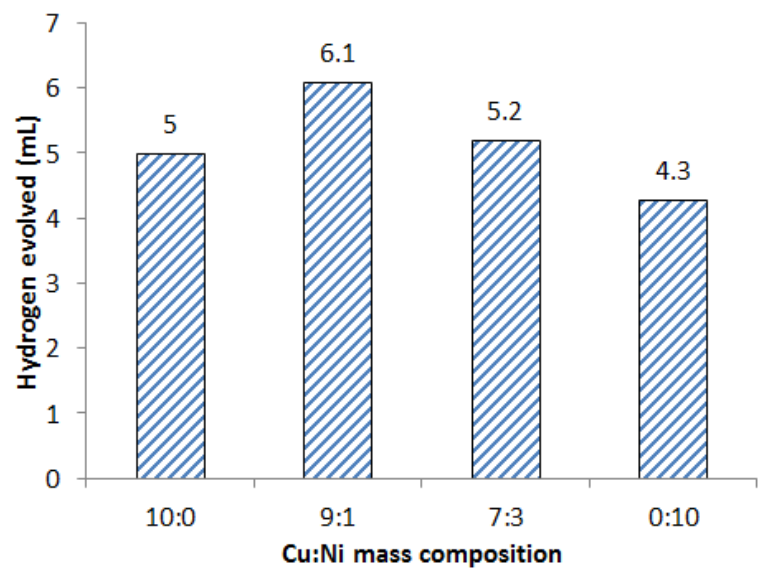

Fig. 5. The effect of $\mathrm{Cu}$ :Ni mass composition of photocatalyst with $10 \mathrm{wt} \%$ total metal loading on hydrogen production.

Fig. 6 revealed that as the total metal loading of the photocatalysts ( $\mathrm{Cu}: \mathrm{Ni}$ mass composition of 9:1) was increased from $5 \mathrm{wt} \%$ to $10 \mathrm{wt} \%$, the amount of hydrogen gas evolved increased from $3.0 \mathrm{~mL}$ to $6.1 \mathrm{~mL}$. The presence of metal was able to inhibit the electron-hole recombination process [29]. However, when the total metal loading was increased to $11 \mathrm{wt} \%$, the photocatalytic activity was reduced to $5.0 \mathrm{~mL}$ hydrogen evolved. Further increase in total metal loading showed lowered performance. As the total metal loading increases, the metal sites will act as electron-hole recombination centers due to electrostatic forces between the negatively charged metal sites and the positively charged holes [29-30]. The optimum loading for bimetallic $\mathrm{Cu}-\mathrm{Ni}$ was $10 \mathrm{wt} \%$.

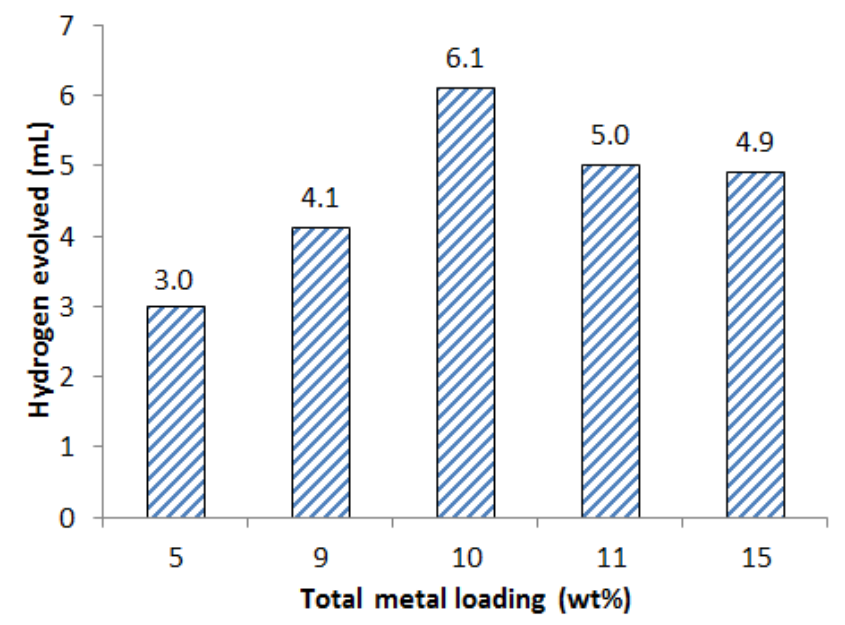

Fig. 6. The effect of total metal loading of photocatalyst (Cu:Ni mass composition 9:1) on hydrogen production.

From Fig. 7, the effect of glycerol amount on hydrogen production was investigated using $10 \mathrm{wt} \%$ 9Cu1Ni. When 2.0 $\mathrm{mL}$ of glycerol was added, tremendous increase in the amount of hydrogen produced $(9.5 \mathrm{~mL})$ was observed. At this stage glycerol acts as a hole scavenger [18] diminishing the effect of electron-hole recombination. Although the amount of hydrogen produced decreased when more glycerol was added, the overall effect was enhancement of performance compared to without glycerol addition. The decreased performance with higher amount of glycerol may be due to the competitive adsorption of glycerol, its intermediates and water onto the photocatalyst surface [31].

The intermediate products identified from glycerol photooxidation were glyceraldehyde, glycolic acid, and oxalic acid. The use of glycerol as sacrificial agent for hydrogen production from water serves not only to enhance the photocatalytic performance but also the generation of valueadded products from the biodiesel by-product.

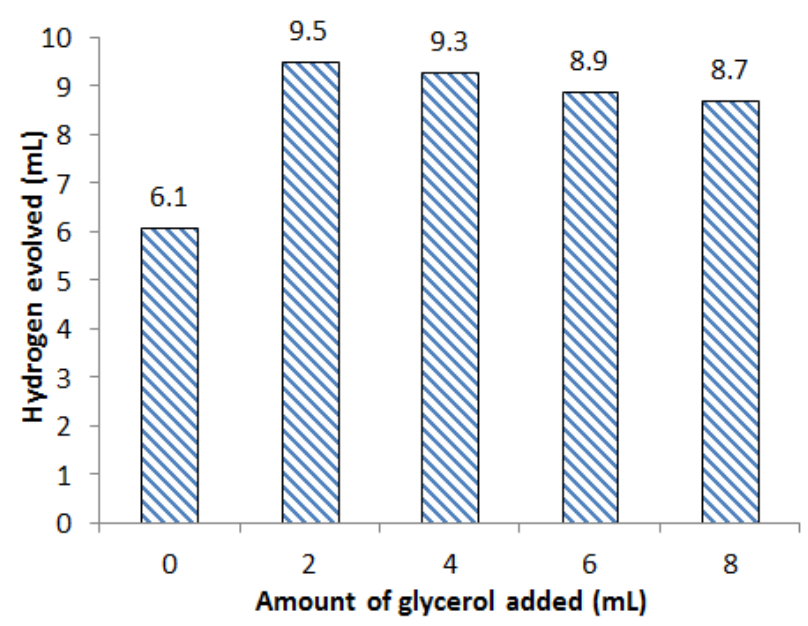

Fig. 7. The effect of glycerol amount on hydrogen production using $10 \mathrm{wt} \%$ 9Cu1Ni.

\section{CONCLUSION}

The photocatalysts displayed high metal dispersion. Particles were spherical shaped with slight agglomeration with size ranging from $20-40 \mathrm{~nm}$. The addition of $\mathrm{Cu}$, $\mathrm{Ni}$ or bimetallic $\mathrm{Cu}-\mathrm{Ni}$ onto $\mathrm{TiO}_{2}$ led to reduction in band gap from $3.16 \mathrm{eV}$ to $2.78 \mathrm{eV}$ for $10 \mathrm{wt} \% 9 \mathrm{Cu} 1 \mathrm{Ni}$ photocatalyst. This led to enhancement in the hydrogen production $(6.1 \mathrm{~mL})$ under visible light illumination compared to $\mathrm{TiO}_{2}$. The addition of $2.0 \mathrm{~mL}$ of glycerol as hole scavenger further enhanced the solar hydrogen production to $9.5 \mathrm{~mL}$. The photooxidation of glycerol under visible light illumination produced glyceraldehyde, glycolic acid and oxalic acid.

\section{ACKNOWLEDGMENT}

The authors would like to acknowledge Universiti Teknologi PETRONAS for providing research facilities and financial support.

\section{REFERENCES}

[1] M. Momirlan, and T. Vezirog, "Recent directions of world hydrogen production", Renewable and sustainable energy reviews, vol. 3, pp. 219231, 1999.

[2] M. Ni, M.K.H. Leung, D.Y.C., and K. Sumathy, "A review and recent developments in photocatalytic water-splitting using $\mathrm{TiO}_{2}$ for hydrogen production”, J. Renewable and Sustainable Energy Reviews, vol. 11, pp 401-425, 2007. 
[3] M. Kitano, M. Matsuoka, M. Ueshima, and M. Anpo, "Recent developments in titanium oxide-based photocatalysts", Applied Catalysis A: General vol. 325, pp.1-14, 2007.

[4] A. Kudo, R. Niishiro, A. Iwase, H. Kato, "Effects of doping of metal cations on morphology, activity, and visible light response of photocatalysts", Chemical Physics, vol 339, pp.104-110, 2007.

[5] J.P. Yasomanee, and J. Bandara, "Multi-electron storage of photoenergy using $\mathrm{Cu}_{2} \mathrm{O}-\mathrm{TiO}_{2}$ thin film photocatalyst", Solar Energy Materials and Solar Cells, vol. 92, pp.348-352, 2008.

[6] J. Premkumar, "Development of Super-Hydrophilicity on NitrogenDoped $\mathrm{TiO}_{2}$ Thin Film Surface by Photoelectrochemical Method under Visible Light”, Chemistry Materials, vol. 16, pp.3980-3981, 2004.

[7] J. Bandara, C.P.K. Udawatta, and C.S.K. Rajapakse, "Highly stable CuO incorporated $\mathrm{TiO}_{2}$ catalyst for photocatalytic hydrogen production from $\mathrm{H}_{2} \mathrm{O}$ ", Journal of Photochemistry and Photobiological Science, vol. 4, no. 11 , pp. 857-861, 2005.

[8] G.L. Chiarello, E. Selli, L. Forni, "Photocatalytic Hydrogen Production Over Flame Spray Pyrolysis-synthesised $\mathrm{TiO}_{2}$ and $\mathrm{Au} / \mathrm{TiO}_{2}$ ", Applied Catalysis B: Environmental, vol. 84, pp. 332-342, 2008.

[9] Z.M. El-Bahy, A.A. Ismail, R.M. Mohamed, "Enhancement of Titania by Doping Rare Earth for Photodegradation of Organic Dye (Direct Blue)", Journal of Hazardous Materials, vol. 166, no.1, pp. 138-143, 2008.

[10] V. Ponec, "Alloy catalysts: the concepts", Applied Catalysis A: General, vol. 222, pp. 31-45, 2001

[11] Y. Liu, D. Liu, "Study of Bimetallic $\mathrm{Cu}-\mathrm{Ni} / \mathrm{Al}_{2} \mathrm{O}_{3}$ Catalysts for Carbondioxide Hydrogenation", Int. Journal of Hydrogen Energy, vol. 24, pp. 351-354, 1999

[12] W.Gao, R. Jin, J. Chen, X. Guang, H. Zheng, F. Zhang, N. Guan, "Titania-supported Bimetallic Catalysts for Photocatalytic Reduction of Nitrate", Catalysis Today, vol. 90, pp. 331-336, 2004

[13] V. Maurino, A. Bedini, M. Minella, F. Rubertelli, E. Pelizzetti, and C. Minero, "Glycerol Transformation Through Photocatalysis: A Possible Route to Value Added Chemicals", Journal of Advanced Oxidation Technologies, vol. 11, no. 2, pp. 184-192, 2008.

[14] V. Augugliaro, H.A. Hamed El Nazer, V. Loddo, A. Mele, G. Palmisano, L. Palmisano, and S. Yurdakal, "Partial photocatalytic oxidation of glycerol in $\mathrm{TiO}_{2}$ water suspensions", Catalysis Today, vol. 151, no. 1-2, pp. 21-28, 2010.

[15] M. Li, Y. Li, S. Peng, G. Lu, and S.B. Li, 2009, "Photocatalytic hydrogen generation using glycerol wastewater over $\mathrm{Pt} / \mathrm{TiO}_{2}$ ", Frontiers of Chemistry in China, vol. 4, no.1, pp. :32-38, 2009.

[16] M. Bowker, P.R. Davies, and L.S. Al-Mazroai, "Photocatalytic Reforming of Glycerol over Gold and Palladium as an Alternative Fuel Source", Catal Lett, vol. 128, pp. 253-255, 2009.

[17] G. Li, N.M. Dimitrijevic, L. Chen, T. Rajh, and K.A. Gray, "Role of Surface/Interfacial $\mathrm{Cu}^{2+}$ Sites in the Photocatalytic Activity of Coupled CuO- $\mathrm{TiO}_{2}$ Nanocomposites", J. Phys. Chem, C, vol. 112, pp. 1904019044, 2008.

[18] V. Gombac, L. Sordelli, T. Montini, J.J. Delgado, A. Adamski, G. Adami, M. Cargnello, S. Bernal, and P. Fornasiero, " $\mathrm{CuO}_{x}-\mathrm{TiO}_{2}$
Photocatalysts for $\mathrm{H}_{2}$ Production from Ethanol and Glycerol Solutions", J. Phys. Chem, A, vol. 114, pp. 3916-3925, 2010.

[19] A.V. Korzhak, N.I. Ermokhina, A.L. Stroyuk, V.K. Bukhtiyarov, A.E. Raevskaya, V.I. Litvin, S.Y. Kuchmiy, V.G. Ilyin, and P.A. Manorik, "Photocatalytic hydrogen evolution over mesoporous $\mathrm{TiO}_{2} /$ metal nanocomposites", Journal of Photochemistry and Photobiology A: Chemistry, vol.198, no. 2-3, pp. 126-134, 2008.

[20] Ela Nurlaela, "Development of $\mathrm{Cu}-\mathrm{Ni} / \mathrm{TiO}_{2}$ bimetallic catalyst for photohydrogen production under visible light illumination", M.Sc. Thesis, Universiti Teknologi PETRONAS, 2011.

[21] Y. Li, M. Cai, J. Rogers, Y. Xu, and W. Shen, "Glycerol-mediated synthesis of $\mathrm{Ni}$ and $\mathrm{Ni} / \mathrm{NiO}$ core-shell nanoparticles," Materials Letters, vol. 60, pp. 750-753, 2006.

[22] L.S. Yoong, F.K. Chong, and B.K. Dutta, "Development of copperdoped $\mathrm{TiO}_{2}$ photocatalyst for hydrogen production under visible light " Energy, vol. 34, pp. 1652-1661, 2009.

[23] J. Escobar, J. A. D. L. Reyes, and T. Viveros, "Nickel on $\mathrm{TiO}_{2}$-modified $\mathrm{Al}_{2} \mathrm{O}_{3}$ sol-gel oxides: Effect of synthesis parameters on the supported phase properties," Applied Catalysis A, vol. 253, pp. 151-163, 2004.

[24] O. V. Komova, A. V. Simakov, V. A. Rogov, D. I. Kochubei, G. V. Odegova, V. V. Kriventsov, E. A. Paukshtis, V. A. Ushakov, N. N. Sazonova, and T. A. Nikoro, "Investigation of the state of copper in supported copper-titanium oxide catalysts," Journal of Molecular Catalysis A, vol. 161, pp. 191-204, 2000.

[25] T. Umebayashi, T. Yamaki, H. Itoh, K. Asai, "Analysis of electronic structures of $3 \mathrm{~d}$ transition metal-dope $\mathrm{TiO}_{2}$ based on band calculation", Journal of Physics and Chemistry Solids, vol. 63, pp. 1909-1920, 2002.

[26] T. Miwa, S. Kaneco, H. Katsumata, T. Suzuki, K. Ohta, S.C. Verma, and K. Sugihara, "Photocatalytic hydrogen production from aqueous methanol solution with $\mathrm{CuO} / \mathrm{Al}_{2} \mathrm{O}_{3} / \mathrm{TiO}_{2}$ nanocomposite," International Journal of Hydrogen Energy, vol. 35, pp. 6554-6560, 2010.

[27] D. Jing, L. Guo, L. Zhao, "Study on the synthesis of Ni doped mesoporous $\mathrm{TiO}_{2}$ and its photocatalytic activity for hydrogen evolution in aqueous methanol solution," Chemical Physics Letters, vol.415, pp. 74-78, 2005.

[28] D.H. Tseng, L.C. Juang and H.H. Huang, "Effect of oxygen and hydrogen peroxide on the photocatalytic degradation of monochlorobenzene in $\mathrm{TiO}_{2}$ aqueous suspension", International Journal of Photoenergy, vol. 2012, pp. 1-9, 2012.

[29] O. Carp, C. L. Huisman, and A. Reller, "Photoinduced Reactivity of Titanium Dioxide", Progress in Solid State Chemistry, vol. 32, pp. 33$117,2004$.

[30] T. Sreethawong, S. Laehsalee, and S. Chavadej, "Use of Pt/N-doped mesoporous-assembled nanocrystalline $\mathrm{TiO}_{2}$ for photocatalytic $\mathrm{H}_{2}$ production under visible light irradiation", Catalysis Communications, vol. 10, pp. 538-543, 2009.

[31] S. Chavadej, P. Phuaphromyod, E. Gulari, P. Rangsunvigit, and T. Sreethawong, "Photocatalytic degradation of 2-propanol by using $\mathrm{Pt} / \mathrm{TiO}_{2}$ prepared by microemulsion technique,"Chemical Engineering Journal, vol. 137, pp. 489-495, 2008.

\section{Creative Commons Attribution License 4.0 (Attribution 4.0 International, CC BY 4.0)}

This article is published under the terms of the Creative Commons Attribution License 4.0 https://creativecommons.org/licenses/by/4.0/deed.en US 